\title{
Prediksi usia pakai baterai pada sistem pencadangan unit 3 PLTU Suralaya
}

\author{
Dini Fauziah ${ }^{1 *}$, Riyan Indra Laksono ${ }^{2}$ \\ ${ }^{1,2}$ Jurusan Teknik Elektro, Fakultas Teknik, Institut Teknologi Nasional Bandung \\ J1. PH.H. Mustofa No. 23, Kota Bandung, Jawa Barat 40124, Indonesia \\ 1*dinifauziah@itenas.ac.id, ${ }^{2}$ riyanil66@gmail.com
}

\begin{abstract}
ABSTRAK
Sistem cadangan sangat penting dan wajib dimiliki dalam sebuah sistem produksi. Sistem ini berfungsi untuk menjaga keandalan dari sistem tersebut. Pembangkit Listrik Tenaga Uap (PLTU) PT. Indonesia Power Suralaya merupakan salah satu perusahaan penghasil listrik yang menggunakan baterai sebagai sistem cadangan, terutama pada peralatan listrik yaitu menggunakan sistem baterai 220 VDC. Pada sistem pencadangan ini terdiri dari 104 sel baterai dan masing-masing sel baterai bernilai 2 VDC berjenis asam timbal. Masalah yang sering terjadi pada sistem baterai tersebut yaitu suhu kerja yang melebihi suhu yang ditentukan oleh spesifikasi baterai untuk bekerja maksimum dikarenakan faktor cuaca lingkungan. Permasalahan ini berdampak terhadap usia pakai baterai menjadi lebih pendek. Oleh karena itu, penelitian ini bertujuan untuk mengetahui pengaruh suhu lebih terhadap usia pakai baterai asam timbal. Data pada penelitian ini diperoleh berdasarkan pengukuran rutin bulanan yang diukur langsung menggunakan thermogun dengan analisis data menggunakan metode regresi linier. Berdasarkan hasil analisis didapat bahwa usia pakai baterai pada saat kondisi ini akan bertahan selama 13 tahun 2 bulan sejak awal dipasang yaitu sejak bulan Februari tahun 2017, dengan usia pakai seharusnya yaitu 20 tahun atau berkurang sekitar 7 tahun $( \pm 35 \%)$ dibandingkan spesifikasinya. Dengan demikian, pada bulan Agustus tahun 2029 baterai direkomendasikan untuk diganti.
\end{abstract}

Kata kunci: baterai asam timbal, suhu, prediksi, usia pakai, regresi linier

\section{ABSTRACT}

Backup system is very important and must exist in a production system. This system serves to maintain the reliability of the system. Electric Steam Power Plant (PLTU) PT. Indonesia Power Suralaya is one of the electricity producing companies that uses batteries as a backup system especially in electric motors using a 220 VDC battery system. In this backup system consists of 104 battery cells and each battery cell is worth 2 VDC of lead acid type. The problem that often occurs in the battery system is that the working temperature exceeds the temperature determined by the battery specifications to work optimally due to environmental weather factors. This problem can result in shorter battery life. Therefore, this study aims to determine the effect of over temperature on lead acid battery life. The data in this study were obtained based on monthly routine measurements which were measured directly using a thermogun with data analysis using the linear regression method. Based on the results of the analysis, it was found that the battery life during this condition will last for 13 years and 2 months since it was initially installed on February 2017, with a lifespan that should be 20 years or 7 years less compared to the specifications. Thus, in August 2029 the battery is recommended to be replaced.

Keywords: battery, temperature, prediction, lifetime, linear regression

\section{PENDAHULUAN}

Listrik dan sumber pembangkitan listrik merupakan energi yang sangat diperlukan. Kebutuhan terhadap sumber energi listrik semakin lama akan meningkat dan pada peningkatan ini harus diiringi oleh ketersediaan sumber energi tersebut. Oleh karena itu, energi listrik sangat berperan dalam seluruh bidang pada kehidupan [1]. Pembangkit Listrik Tenaga Uap (PLTU) adalah salah satu pembangkitan energi listrik dengan memanfaatkan tekanan uap kering dari hasil penguapan air. Air dipanaskan pada boiler sehingga menjadi uap basah kemudian dipanaskan kembali agar menjadi uap kering. Uap kering tersebut disalurkan kepada turbin untuk menggerakkan turbin dan menyalurkan energi mekanik yang didapatkan ke generator melalui rotor generator sehingga menjadi energi listrik. 
PT. Indonesia Power Suralaya adalah salah satu perusahaan penghasil listrik dengan pemasokan listrik yang menggunakan batu bara untuk membangkitkan listrik. PT. Indonesia Power Suralaya mempunyai 7 unit pembangkit. Pada setiap unit memiliki dua jenis baterai sebagai sistem backup (cadangan) apabila terjadi black out sehingga komponen-komponen vital yang tidak boleh padam masih bisa bekerja sesuai fungsinya. Dalam sistem pencadangan energi listrik dapat bersumber dari arus searah (DC) maupun arus bolak balik (AC). Namun, pada sistem penyimpanan energi listrik biasanya digunakan arus searah, salah satunya menggunakan baterai [2].

Berdasarkan pemakaiannya baterai terbagi menjadi dua jenis, yaitu sebagai berikut [3], [4]:

1. Primary battery, pada jenis ini baterai hanya dapat digunakan satu kali penggunaan. Baterai ini memiliki material elektroda yang tidak dapat berlawanan arah ketika dilepaskan.

2. Secondary battery, pada jenis ini baterai dapat digunakan beberapa kali atau dapat diisi ulang. Proses kimia yang terjadi di dalam baterai adalah reversibel atau proses kimia yang berlangsung dua arah, dan bahan aktif dapat kembali ke kondisi semula dengan pengisian sel. Baterai sekunder memiliki beberapa jenis, yaitu lithium ion, lithium polymer, asam timbal, dan nickel-metal hydride [5].

Setiap jenis baterai pasti memiliki gangguan yang berbeda-beda. Selain baterai lithium polymer jenis baterai yang umumnya digunakan untuk sistem pencadangan energi listrik yaitu baterai asam timbal [6].

Beberapa studi terkait penggunaan baterai asam timbal telah dilakukan pada penelitian tedahulu. Baterai asam timbal menggunakan lead peroxide $\left(\mathrm{PbSO}_{4}\right)$ sebagai katoda dari baterai, lead sponge $(\mathrm{Pb})$ sebagai anoda dari baterai dan sulfuric acid $\left(\mathrm{H}_{2} \mathrm{SO}_{4}\right)$ sebagai elektrolit. Kelebihan dari baterai ini yaitu memiliki biaya perawatan yang murah dibandingkan baterai sekunder, sehingga sering digunakan pada sektor industri [7]. Kekurangan dari penggunaan baterai asam timbal yaitu adanya pengendapan timbal yang terjadi pada elektroda sehingga mengurangi efisiensinya dan berakibat pada pengurangan usia pakai dari baterai tersebut [8]. Gangguan yang sering terjadi pada baterai ini yaitu terdapat suhu lebih saat pemakaian yang memiliki dampak pada penurunan usia pakai baterai, sehingga kapasitas pemakaiannya juga akan menurun. Faktor yang dapat mempengaruhi kapasitas baterai yaitu tingkat debit (pelepasan) dan suhu lingkungan [9].

PLTU Suralaya menggunakan dua jenis tegangan yaitu yaitu sistem baterai 125 VDC dan 220 VDC. Pada sistem baterai 125 VDC digunakan sebagai sistem cadangan untuk seluruh panel sistem pembangkitan dan sistem 220 VDC digunakan sebagai sistem pencadangan listrik untuk peralatan motor-motor listrik. Sistem baterai 220 VDC terdiri dari 104 baterai asam timbal dengan masingmasing tegangan yaitu 2 VDC.

Penelitian ini bertujuan untuk memperkirakan usia pakai baterai saat suhu kerja baterai melebihi suhu yang sesuai spesifikasinya menggunakan metode analisis regresi linier. Dengan metode ini, pengguna baterai dapat menentukan jadwal yang tepat untuk penggantian baterai sesuai dengan kondisi suhu lingkungan yang sebenarnya di lapangan. Penelitian ini merupakan lanjutan dari penelitian yang telah dilakukan oleh [1]. Pembeda dari penelitian ini dengan penelitian sebelumnya yaitu penelitian ini menggunakan metode pengukuran secara langsung selama 6 bulan pada sistem baterai 220 VDC, yaitu sejak Agustus 2019 hingga Januari 2020. Pengukuran ini dilakukan pada saat pengecekan rutin bulanan. Alat yang digunakan untuk melakukan pengukuran yaitu thermogun. Dan metode analisis yang digunakan yaitu regresi linier.

\section{METODE PENELITIAN}

Gambar 1 merupakan diagram blok yang dilakukan pada penelitian ini. Komponen utama dalam proses prediksi yaitu jumlah data yang didapat. Setelah data sudah didapat proses prediksi dapat dimulai. Untuk mendapatkan persamaan regresi linier diperlukan variabel A dan B, dimana kedua variabel tersebut dapat dicari dengan persamaan (1) dan persamaan (2).

Setelah diperoleh persamaan regresi linier penting dilaksanakan uji regresi untuk mengetahui seberapa dekat hasil pengukuran dengan prediksi, dimana jumlah atau nilai $\mathrm{x}$ sama dengan jumlah banyaknya data yang didapat. Jika prediksi terlalu jauh maka perlu dilakukan pengecekan pada proses pencarian nilai variabel A dan B. Namun, jika sudah sesuai atau mendekati prediksi dapat dilakukan dengan memasukkan variabel sebanyak variabel x per bulan yang diinginkan untuk mengetahui suhu pada bulan x. Setelah nilai x dimasukkan akan didapat hasil dari prediksi dan untuk mengetahui 
prediksinya sudah sesuai atau tidak dapat dibandingkan dengan kurva suhu terhadap design life. Setelah dibandingkan dengan kurva design life, apabila kedua hasil prediksi dan kurva design life memiliki nilai yang relatif sama, maka hasil prediksi usia pakai tersebut telah sesuai dan menyatakan nilai yang sebenarnya sehingga diperoleh usia pakai dari baterai tersebut.

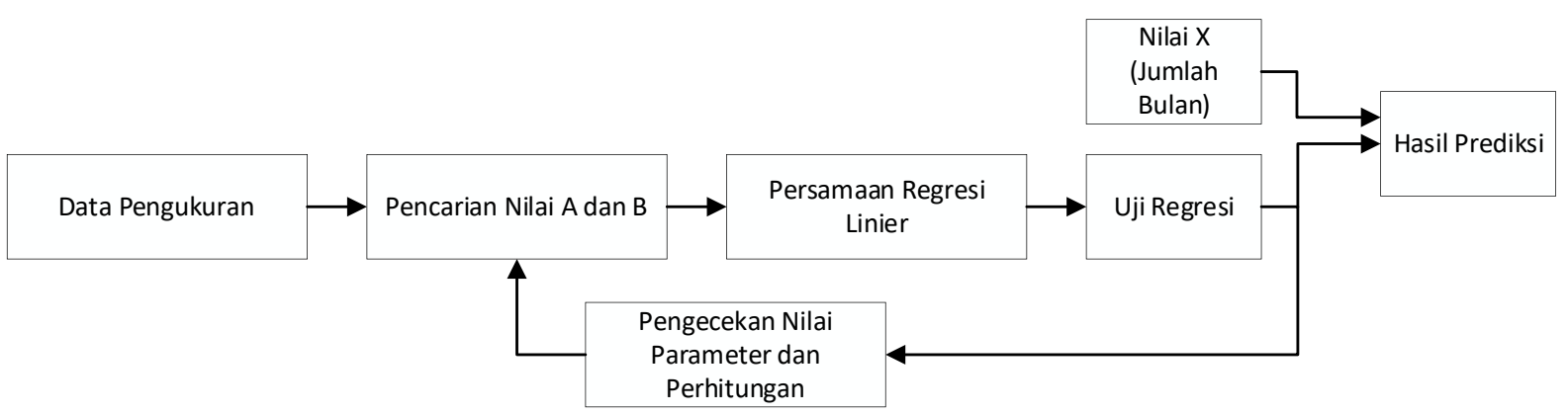

Gambar 1. Diagram blok

\subsection{Metoda Pengukuan}

Proses pengukuran pada Gambar 2 dilakukan pada setiap sel baterai. Nilai yang diukur pada masing-masing baterai meliputi suhu sel baterai, tegangan sel baterai, dan resistansi sel baterai. Pengukuran parameter-parameter tersebut dilakukan menggunakan thermogun sebagai alat ukur suhu sel baterai dan battery tester sebagai alat pengukur nilai tegangan dan resistansi sel baterai. Proses pengukuran baterai dilakukan oleh teknisi satu per satu, sehingga dalam prosesnya diperlukan pengukuran sebanyak 104 kali. Pengukuran sel baterai dilakukan rutin satu kali dalam satu bulan dan dilakukan pada waktu yang sama [6]. Selain melakukan pengukuran pada ketiga parameter tersebut, teknisi juga melakukan pengecekan pada ketinggian larutan pada sel baterai.

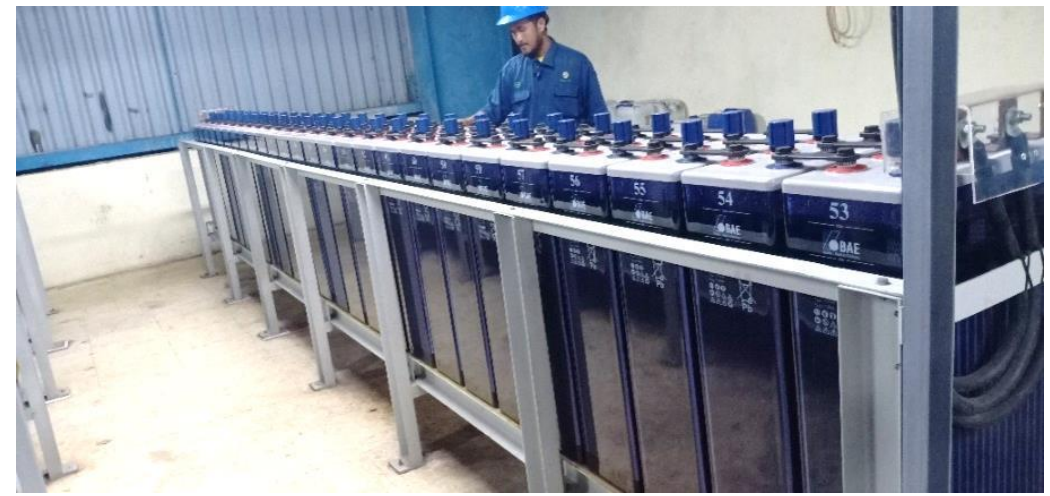

Gambar 2. Proses pengukuran baterai

\subsection{Standar Pengukuran}

Penelitian ini menggunakan dua sumber parameter standar penggunaan, yaitu International Electrotechnical Commission (IEC) dan parameter standar yang telah diberikan oleh pembuat baterai. Berdasarkan IEC 62485-2 mengenai standar dari baterai asam timbal, standar internasional ini memberikan persyaratan pada aspek keselamatan yang terkait dengan ereksi, penggunaan, inspeksi, pemeliharaan, dan pembuangan. Diketahui bahwa tegangan dan arus pada baterai saat pengisian (mode float) bernilai $\mathrm{U}_{\text {float }}=2,23 \mathrm{~V} / \mathrm{sel}$ dan $\mathrm{U}_{\text {float }}=1 \mathrm{~mA}$ per Ah. Serta saat pengisian pada model pengisian cepat dengan $\mathrm{U}_{\text {boost }}=2,4 \mathrm{~V} / \mathrm{sel}$ dan $\mathrm{I}_{\text {boost }}=4 \mathrm{~mA}$ per Ah [10].

Berdasarkan standar dari penggunaan baterai yang telah ditentukan oleh pembuat baterai nilai maksimal penyerapan energi yaitu dengan tegangan 2,55 V/sel dan dengan maksimum arus sebesar 6 x 110 A dengan waktu penyerapan yang disarankan yaitu 180 menit dan waktu penyerapan muatan penuh yaitu 6 jam. Nilai tegangan pada jenis pengisian mengambang (float) yang disarankan yaitu $2,23 \mathrm{~V} / \mathrm{sel}$, dengan koreksi suhu pada $<20^{\circ} \mathrm{C}$ yaitu $-3 \mathrm{mV} / \mathrm{K}$ dan pada $\geq 20^{\circ} \mathrm{C}$ yaitu $0 \mathrm{mV} / \mathrm{K}$ [11]. 


\subsection{Regresi Linier}

Metode pendekatan regresi linier dapat digunakan untuk melakukan prediksi usia pakai dari baterai. Berikut adalah persamaan dari regresi linier [12], [13].

$$
\begin{aligned}
A & =\frac{(\Sigma \mathrm{y})\left(\Sigma x^{2}\right)-(\Sigma \mathrm{x})(\Sigma \mathrm{xy})}{n\left(\Sigma x^{2}\right)-(\Sigma \mathrm{x})^{2}} \\
B & =\frac{n(\Sigma \mathrm{xy})-(\Sigma \mathrm{x})(\Sigma \mathrm{y})}{n\left(\Sigma x^{2}\right)-(\Sigma \mathrm{x})^{2}} \\
y & =f(x)=\mathrm{A}+\mathrm{Bx}
\end{aligned}
$$

dengan:

A $\quad=$ konstanta (intercept), perpotongan dengan sumbu vertikal

$\mathrm{B} \quad=$ konstanta regresi (slope)

$\mathrm{n} \quad=$ banyak jenis data

$\mathrm{x} \quad=$ waktu pemakaian baterai (bulan)

$\mathrm{y} \quad=$ suhu pada masing-masing baterai (celcius)

$\Sigma \mathrm{x} \quad=$ jumlah dari variabel $\mathrm{x}$

$\Sigma \mathrm{y} \quad=$ jumlah dari variabel $\mathrm{y}$

$\Sigma \mathrm{x}^{2} \quad=$ jumlah dari variabel $\mathrm{x}$ kuadrat

$\Sigma x y=$ jumlah perkalian dari variabel $\mathrm{x}$ dan variabel $\mathrm{y}$

\section{HASIL DAN PEMBAHASAN}

Data hasil pengukuran suhu baterai dapat dilihat pada Gambar 3. Garis merah putus-putus pada Gambar 3 merupakan nilai standar (nilai normal) dari suhu masing-masing sel baterai yang digunakan pada PT. Indonesia Power. Garis melengkung dengan berbagai warna merupakan nilai suhu 104 buah baterai berdasarkan hasil pengukuran selama 6 bulan dengan waktu yang sama setiap bulannya. Data pengukuran baterai diperoleh dari pengukuran rutin yang telah dilakukan oleh teknisi pada PT. Indonesia Power Suralaya sejak bulan Agustus 2019 hingga bulan Januari 2020. Pengukuran suhu pada masing-masing sel baterai diukur secara langsung menggunakan thermogun. Pengukuran ini dilakukan setiap bulan dan pada tanggal serta waktu yang sama [6].

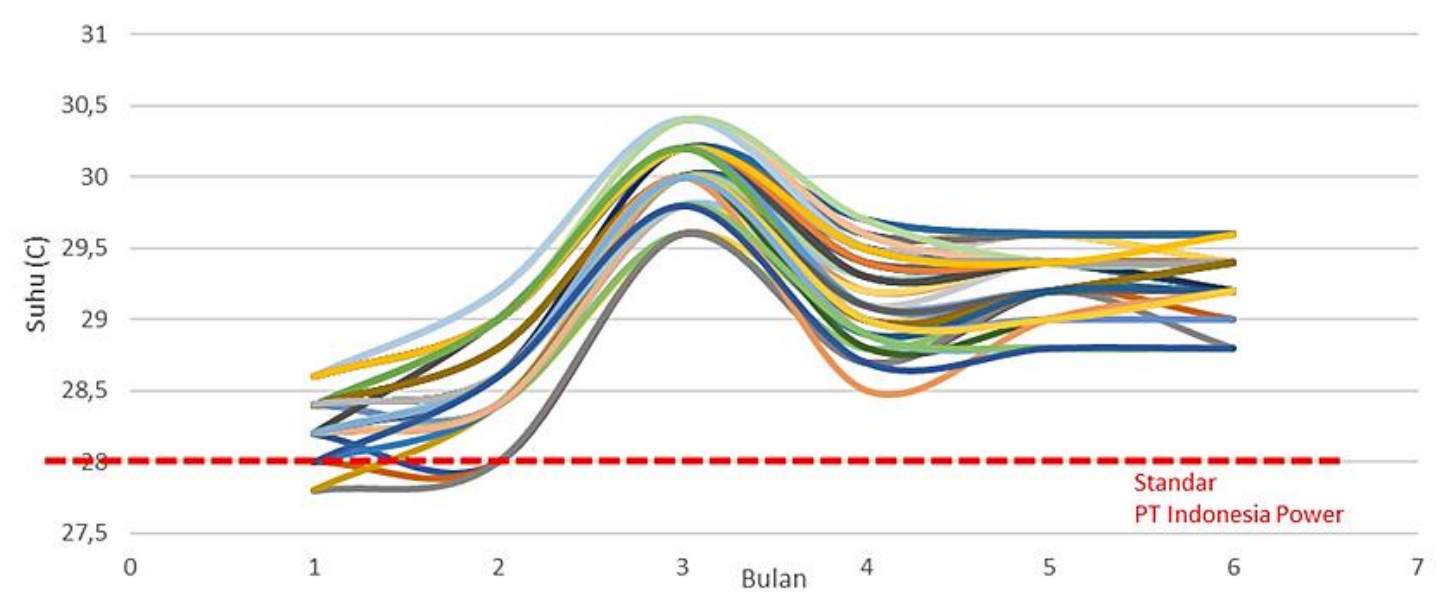

Gambar 3. Data pengukuran suhu baterai

Gambar 4 merupakan grafik suhu lingkungan. Garis jingga pada Gambar 4 merupakan nilai suhu lingkungan tertinggi di PLTU Suralaya sejak bulan Agustus 2019 hingga Januari 2020. Garis biru muda merupakan nilai rata-rata suhu lingkungan di PLTU Suralaya sejak bulan Agustus 2019 hingga Januari 2020, dan garis biru tua merupakan nilai terendah suhu lingkungan di PLTU Suralaya sejak bulan Agustus 2019 hingga Januari 2020. Gambar 4 adalah data suhu lingkungan di PLTU Suralaya, dengan asumsi suhu lingkungan (di luar ruangan) sama dengan suhu di dalam ruangan [14]. 


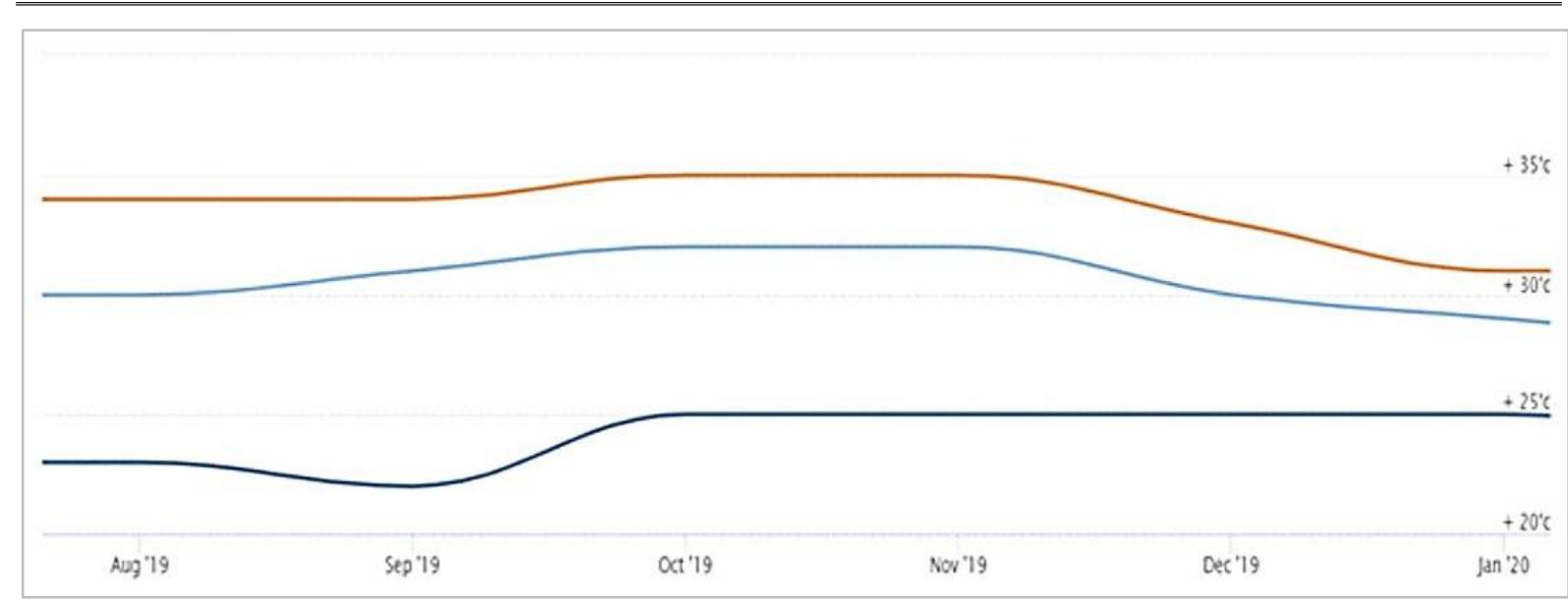

Gambar 4. Data suhu lingkungan

Suhu lingkungan merupakan salah satu faktor dari peningkatan suhu baterai. Berdasarkan Gambar 4 menunjukkan nilai suhu rata-rata sebesar $\pm 32^{\circ} \mathrm{C}$. Pada Gambar 3 terjadi peningkatan suhu baterai pada bulan ketiga, yaitu Oktober 2019 jika dibandingkan dengan Gambar 4 hal itu sesuai dengan adanya peningkatan suhu lingkungan pada bulan tersebut.

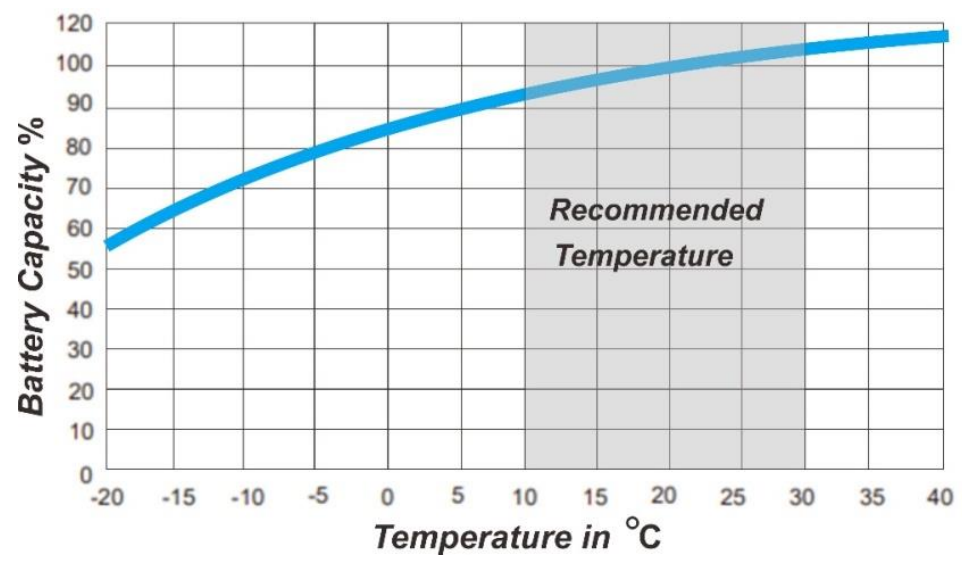

Gambar 5. Peningkatan suhu terhadap kapasitas baterai

Salah satu faktor yang dapat mempengaruhi kapasitas baterai yaitu suhu [11]. Pada Gambar 5 terlihat bahwa semakin besar kapasitas pengisian baterai maka suhu kerja baterai juga semakin tinggi sehingga dari faktor pengisian itu sendiri dapat menambah peningkatan suhu baterai. Rekomendasi suhu kerja pada baterai yaitu antara $10^{\circ} \mathrm{C}$ sampai dengan $30^{\circ} \mathrm{C}$. Umumnya kapasitas dari sebuah baterai selalu dijaga dalam kondisi $100 \%$. Pada Gambar 3 suhu tertinggi baterai adalah $29,8^{\circ} \mathrm{C}$. Apabila dibandingkan dengan Gambar 5 kondisi baterai tersebut masih dalam suhu rekomendasi operasi baterai.

Tabel 1. Data regresi linier

\begin{tabular}{|c|c|c|c|c|}
\hline $\mathbf{x}$ & $\mathbf{y}$ & $\mathbf{x}^{\mathbf{2}}$ & $\mathbf{y}^{\mathbf{2}}$ & $\mathbf{x y}$ \\
\hline 1 & 27,8 & 1 & 772,84 & 27,8 \\
\hline 2 & 28 & 4 & 784 & 56 \\
\hline 3 & 29,6 & 9 & 876,16 & 88,8 \\
\hline 4 & 28,7 & 16 & 823,69 & 114,8 \\
\hline 5 & 29,2 & 25 & 852,64 & 146 \\
\hline 6 & 28,85 & 36 & 829,44 & 172,8 \\
\hline
\end{tabular}


Tabel 1 adalah data yang diperlukan untuk memperoleh persamaan regresi linier, dengan $X$ adalah bulan dan Y adalah suhu baterai saat bulan tersebut. Dengan demikian, diperoleh persamaan akhir sebagai berikut:

$$
y=f(x)=27,913+0,22 x
$$

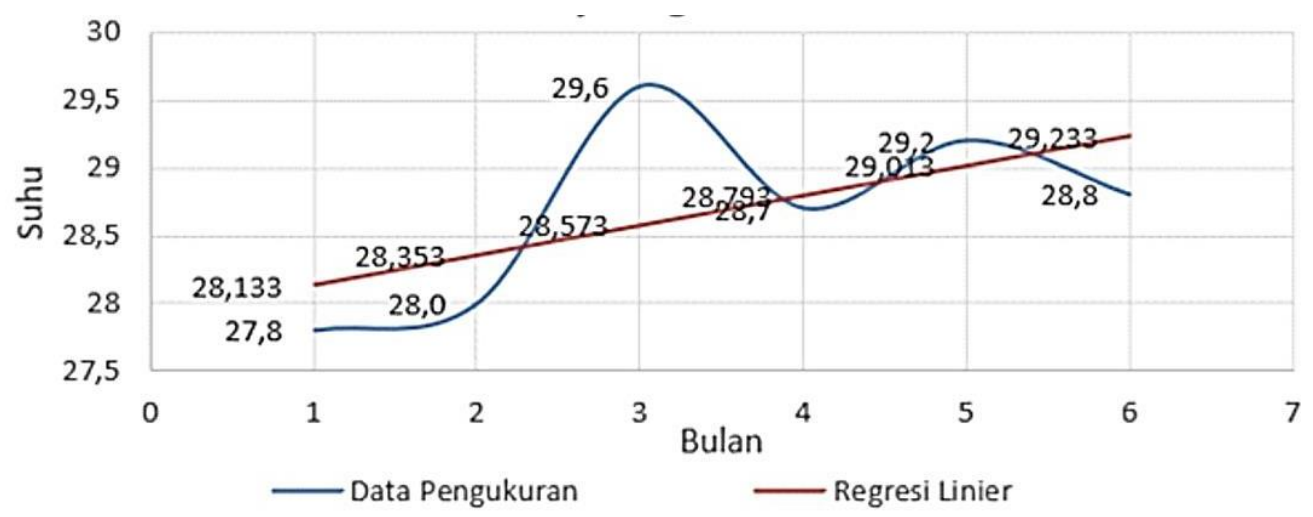

Gambar 6. Uji regresi linier

Berdasarkan Gambar 6 terlihat bahwa nilai uji regresinya masih mendekati nilai dari pengukuran suhu baterai dengan error 5\% sehingga persamaan dapat digunakan untuk melakukan prediksi usia pakai baterai. Berdasarkan persamaan 4 yang telah diperoleh sebelumnya, nilai x yang dimasukkan yaitu 150. Nilai 150 adalah nilai acak yang dipilih untuk uji coba prediksi dan hasil prediksi dapat dilihat pada Gambar 7.

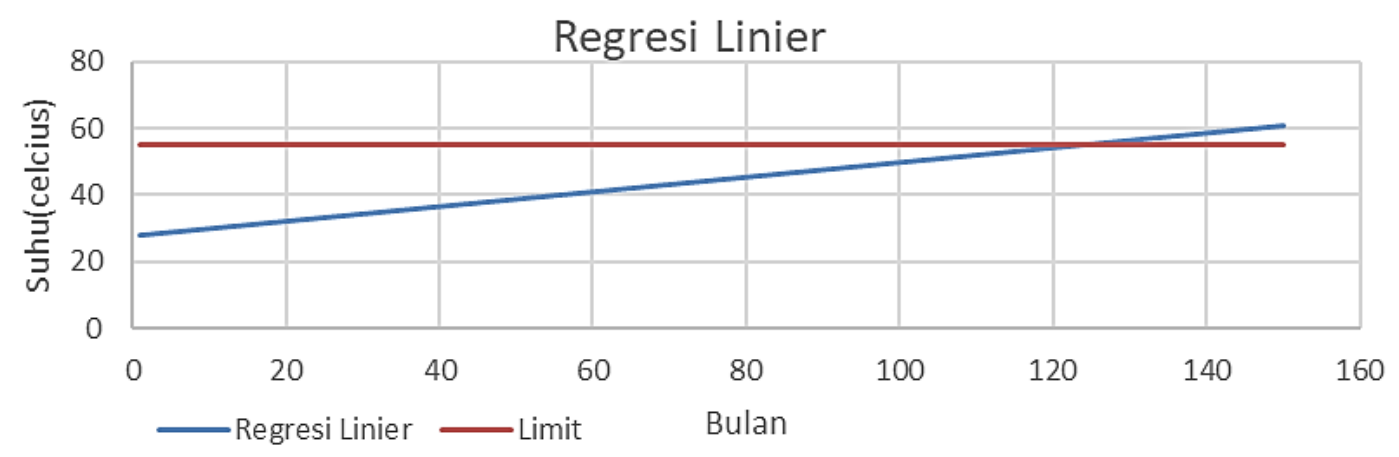

Gambar 7. Kurva regresi linier

Dari Gambar 7 terdapat garis berwarna merah, garis tersebut adalah kelebihan suhu maksimum baterai yang diizinkan dari spesifikasi yaitu $55^{\circ} \mathrm{C}$ [11]. Apabila diasumsikan suhu baterai naik terus menerus diperoleh bahwa usia pakai baterai akan bertahan selama 13 tahun 2 bulan. Usia pakai tersebut terhitung sejak pemasangan pertama, sehingga apabila usia pakai sudah mencapai 13 tahun 2 bulan maka baterai harus diganti dengan baterai yang baru. Hasil prediksi ini diasumsikan berlaku apabila tidak ada perbaikan sirkulasi udara yang dilakukan oleh pengguna.

Berdasarkan Gambar 8 terlihat bahwa setiap perubahan suhu maka design life akan menurun, artinya kinerja dari baterai akan berkurang. Berkurangnya persentase design life tergantung dari besar kecilnya kenaikan suhu. Pada saat suhu baterai dalam keadaan $20^{\circ} \mathrm{C}$ maka design life-nya akan $100 \%$. Hal ini dapat dihubungkan dengan standar yang digunakan oleh pembuat baterai, yaitu suhu $20^{\circ} \mathrm{C}$ tersebut merupakan suhu saat kapasitas baterai 100\%. Pada design life 100\% baterai akan berumur 20 tahun [11]. 


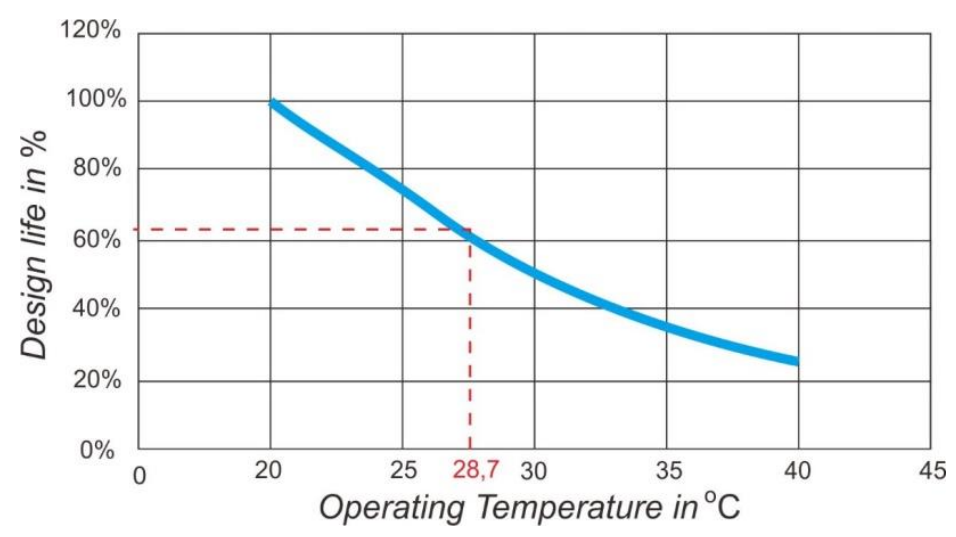

Gambar 8. Kurva hubungan antara suhu terhadap design life

Berdasarkan gambar tersebut apabila suhu baterai berkisar $28,7^{\circ} \mathrm{C}$ sesuai dengan suhu baterai yang diteliti maka umur pakai baterai akan berkurang sebesar $\pm 35 \%$ atau design life baterai akan menjadi $\pm 65 \%$, sehingga sesuai analisis baterai akan memiliki usia pakai selama \pm 13 tahun. Jika Gambar 8 dibandingkan dengan hasil prediksi pada Gambar 7, diperoleh bahwa usia pakai baterai pada saat kondisi ini akan bertahan selama 13 tahun 2 bulan sejak awal dipasang yaitu sejak bulan Februari tahun 2017, dengan usia pakai seharusnya yaitu 20 tahun atau berkurang sekitar 7 tahun dibandingkan spesifikasinya. Dengan demikian, pada bulan Agustus tahun 2029 baterai direkomendasikan untuk diganti.

\section{KESIMPULAN}

Penelitian ini telah berhasil membuktikan bahwa usia pakai (lifetime) baterai akan mengalami penurunan apabila terjadi kenaikan suhu di atas standar yang telah ditetapkan. Pada design life 100\% baterai akan berusia 20 tahun pemakaian. Namun, berdasarkan penelitian lifetime baterai akan bertahan selama 13 tahun 2 bulan akibat terjadinya penurunan design life atau terjadi pengurangan usia pakai baterai selama 6 tahun 10 bulan akibat kenaikan suhu. Dengan demikian, sejak pemasangan pada bulan Februari 2017, maka pada bulan Agustus tahun 2029 baterai direkomendasikan untuk ganti. Penelitian berikutnya dapat dilakukan dengan menambah jumlah variabel yang dianalisis atau menggunakan metode prediksi lainnya sehingga proses prediksi akan lebih akurat.

\section{UCAPAN TERIMA KASIH}

Terima kasih kepada PT. Indonesia Power Suralaya karena membantu sebagai penyedia tempat dan data penelitian.

\section{REFERENSI}

[1] I. A. Wibowo, C. Sudibyo, and B. Basori, "Pengaruh Penggunaan Battery Life Extender Technology Terhadap Temperatur Charging Dan Berat Elektrolit Pada Yuasa Lead Acid Battery Tipe Liquid Vented 12V 5Ah," J. Ilm. Pendidik. Tek. dan Kejuru., vol. 10, no. 1, pp. 54-62, 2017.

[2] A. H. Sabry, W. Z. W. Hasan, Y. Alkubaisi, and M. Z. A. Ab-Kadir, "Battery Backup Power System for Electrical Appliances with Two Options of Primary Power Sources," in 2018 IEEE 5th International Conference on Smart Instrumentation, Measurement and Application (ICSIMA), 2018, pp. 1-5.

[3] M. T. Afif and I. A. P. Pratiwi, "Analisis Perbandingan Baterai Lithium-Ion, Lithium-Polymer, Lead Acid dan Nickel-Metal Hydride pada Penggunaan Mobil Listrik - Review," J. Rekayasa Mesin, vol. 6, no. 2, pp. 95-99, 2015.

[4] H. Wahyu, "Pemeliharaan Sistem DC Power," Lap. Kerja Prakt., p. 32, 2016.

[5] M. Udin, B. S. Kaloko, and T. Hardianto, "Peramalan Kapasitas Baterai Lead Acid pada Mobil Listrik Berbasis Levenberg Marquardt Neural Network,” Berk. SAINSTEK, vol. 5, no. 2, pp. 112-117, 2017.

[6] I. Power, "Indonesia Power," pp. 5-7, 2016.

[7] R. D. Barkah and S. Hidayat, "Simulasi Charge Discharge Model Baterai Lead Acid," J. Ilmu dan Inov. Fis., vol. 3, no. 2, pp. 128-134, 2019.

[8] M. Ghufron, P. B. Kurriawan, I. Istiroyah, and P. A. Cholisina, "ANALISIS EFISIENSI ENERGI FLOW BATERAI LEAD ACID KEADAAN STATIS DAN DINAMIS," ROTOR, vol. 10, no. 2, pp. 42-46, 2017. 
[9] M. A. Fatullah, A. Rahardjo, and F. Husnayain, "Analysis of discharge rate and ambient temperature effects on lead acid battery capacity," in 2019 IEEE International Conference on Innovative Research and Development (ICIRD), 2019, pp. 1-5.

[10] (2010) IEC 62485-2:2010 | IEC Webstore | rural electrification, energy storage, battery, energy efficiency, smart city. [Online]. Available: https://webstore.iec.ch/publication/7091.

[11] (2020) HOPPECKE Batterien GmbH \& Co. KG. Installation, commissioning and operating instructions, for vented stationary lead-acid batteries, pp. 1-68, 2020. [Online]. Available: https://www.hoppecke.com/fileadmin/Redakteur/HoppeckeMain/Products/Downloads/Montagehandbuch_ geschl_EN_final.pdf.

[12] N. Kusumawati, F. Marisa, and I. D. Wijaya, "PREDIKSI KURS RUPIAH TERHADAP DOLLAR AMERIKA DENGAN MENGGUNAKAN METODE REGRESI LINEAR,” J I M P - J. Inform. Merdeka Pasuruan, vol. 2, no. 3, pp. 45-56, 2017.

[13] S. Ningsih and H. H. Dukalang, "Penerapan Metode Suksesif Interval pada Analsis Regresi Linier Berganda," Jambura J. Math., vol. 1, no. 1, pp. 43-53, 2019.

[14] (2021) World Weather Online. [Online]. Available: https://www.worldweatheronline.com/suralayaweather-averages/banten/id.aspx. 